\title{
Method for the detection of significant bacteriuria in large groups of patients
}

\author{
D. A. LEIGH AND J. D. WILLIAMS
}

From the Department of Pathology, Edgware General Hospital

SYNOPSIS A measured area of blotting paper was used as a vehicle for transferring a constanto aliquot of urine on to the surface of a culture medium. The number of bacterial colonies growing $\vec{v}$ in the inoculum area of the medium corresponded to the number of organisms in the urine. Oner thousand, two hundred and seventy-five urines from women attending an ante-natal clinic wereet tested by this method, and the results compared with the results of quantitative bacterial counting and of triphenyl tetrazolium chloride (T.T.C.) tests. The method was found to be a simple, cheap, and reliable way of screening urine specimens for significant bacteriuria.

The increased incidence of urinary tract infection, often persisting asymptomatically, which has been found in certain sections of the population, notably pregnant women (Kaitz and Hodder, 1961 ; Monzon, Armstrong, Pion, Deigh, and Hewitt, 1963), has led to a search for screening tests which are simple to perform, use the minimum of materials, and need not be done by skilled technicians. Quantitative bacterial counting by the pour-plate technique, first popularized by Kass (1956), is now recognized as being the most reliable method of diagnosing the presence of infection in the urinary tract but it is time consuming and needs many materials.

Ryan, Hoody, and Luby (1962) suggested the use of filter paper as a means of simplifying procedures for quantitative bacterial counting. Strips of filter paper of known dimensions were dipped into broth cultures and used to transfer organisms to solid culture media by making an impression of a measured area of the filter paper on to the surface of the medium. They found that the number of bacteria remaining on the surface of the paper depended on the porosity of the paper, those with the finest grain filtering out the greatest number of organisms on to the surface. Using strips of paper of standard porosity the number of organisms filtered out remained constant. The method was applied to a few urine specimens. Eleven examples were given and it was suggested that the method might prove useful for testing urines on a large scale. We have used strips of blotting paper in a similar way to screen the urine of pregnant women for bacteriuria in conjunction with other tests and this paper evaluates the results obtained.

Received for publication 8 May 1964.

\section{METHODS}

THE PAPER STRIP A Postlip Mill 633 fibre-free, flufflesspaper supplied to the laboratory for use as blotting papero was used for the paper strips. Strips were cut 3 in. long ${ }^{\circ}$ by $\frac{1}{4}$ in. wide and a fold was made across the strip $\frac{1}{2}$ in. from one end (Fig. 1). The $\frac{1}{4}$ in. $\times \frac{1}{2}$ in. rectangle wass the inoculum area used to make an impression on the culture medium. The strips were sterilized by heating at $160^{\circ} \mathrm{C}$. for one hour.

THE TEST The test was performed by dipping the wholes of the angulated end of the paper strip into the urine specimen or bacterial suspension, removing the paper? and allowing the excess fluid to be absorbed before making an impression of the inoculum area on to the surface of a well-dried MacConkey agar plate. The culture plate was then incubated overnight and the number of colonies growing in the inoculum area was counted. In reading the results only colony counts of up to 50 per inoculum area were easily counted with oD without a hand lens. Above this level the results weres recorded in two categories, + when more than 50 colonies were present but the colonies were mainly discrete, an ++ when there was confluent growth.

The investigation of the test was divided into two stages. First the preparation of standard calibrated curves using bacterial suspensions of known concentra ${ }_{0}$ tion of each organism, and, secondly, the evaluation of the results of the test as used for the routine screening of urines from women attending the ante-natal clinic for the first time.

PREPARATION OF CALIBRATION CURVES In the preparation of standard curves a number of different organisms were used. Urinary pathogens of bacillary form (Escherichiơ coli, Proteus mirabilis, paracolon spp, atypical colifornक spp, and Aerobacter aerogenes) and of coccal forng (Staphylococcus albus and Streptococcus faecalis) were् 


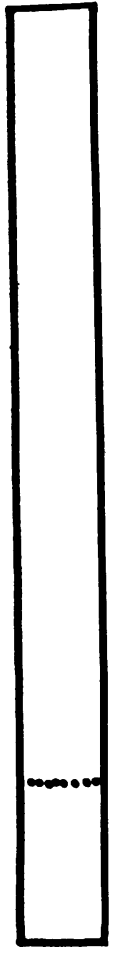

FIG. 1 .

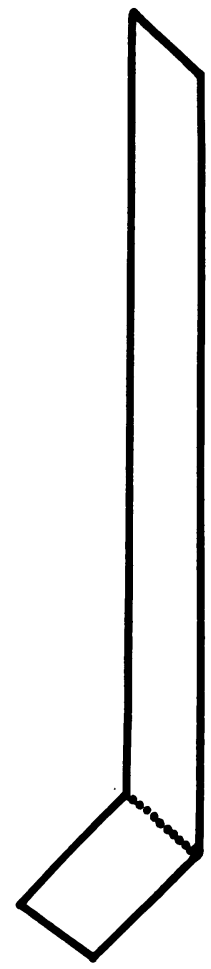

FIG. 1. Blotting paper strip. The dimensions of the ruled area are $\frac{1}{2}$ in. $\times \frac{1}{4}$ in.

FIG. 2. Example of a culture plate used in the preparation of calibration curves.

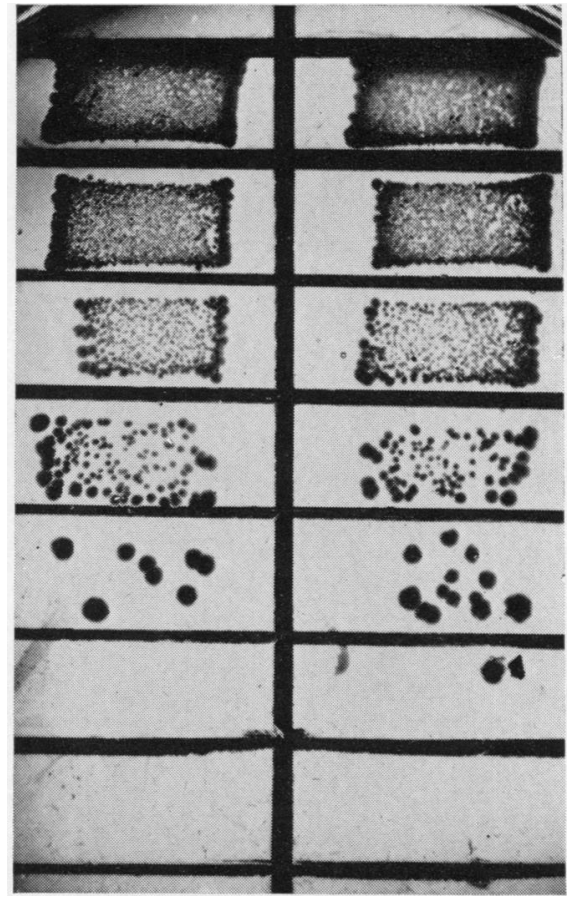

FIG. 2 . obtained in pure culture from routine urine specimens sent to the laboratory. An overnight broth culture of each organism was used neat and diluted $\times \frac{1}{4}, \times \frac{1}{2}$, and $\times \frac{3}{4}$. From these primary dilutions serial tenfold dilutions were made in broth and the paper strip test was carried out in duplicate from the secondary dilutions (Fig. 2).

Quantitative counts were performed on the primary dilutions using both a surface viable count and a modification of the Miles and Misra (1938) technique. In order to obtain sufficient points for an accurate calibration curve the procedure was repeated three times with each organism. From these results curves were plotted on log graph paper (Figs. 3 and 4).

SCREENING PROCEDURE Specimens of urine were collected under standard conditions which included vulval toilet and immediate refrigeration of the urine at $4^{\circ} \mathrm{C}$. after voiding. Specimens of urine were collected from 1,275 women. In the laboratory the paper strip test was performed in duplicate, together with a surface viable count and the T.T.C. test as described by Simmons and Williams (1962). A comparison was made of these results. All urines which showed a positive screening test and/or contained over 100,000 organisms per ml. were examined by standard bacteriological methods which included microscopy of the deposit and culture on to blood agar and MacConkey agar plates. The supernatant fluid was tested for protein.

\section{RESULTS}

CALIBRATION CURVES It was found that all bacilli gave similar curves and the results are plotted together in Figure 3. This showed that a count of 100,000 bacilli per $\mathrm{ml}$. of broth is represented by 25 colonies per inoculum area. Strep. faecalis and Staph. albus gave curves similar to each other but slightly different from the curves given by the bacilli. Figure 4 shows that a count of 100,000 cocci per $\mathrm{ml}$. of broth is represented by 30 colonies per inoculum area.

These two levels were accepted as representing 100,000 organisms per $\mathrm{ml}$. in the screening procedure (Table I).

TABLE I

NUMBER OF COLONIES PER INOCULUM ARLA BY BLOTTING-PAPER METHOD COMPARED WITH SURFACE VIABLE COUNT

\begin{tabular}{lll}
$\begin{array}{l}\text { Surface Viable Count } \\
\text { (organisms per ml.) }\end{array}$ & $\begin{array}{l}\text { Blotting Paper Method } \\
\text { (colonies per inoculum area) }\end{array}$ \\
\cline { 2 - 3 } & Bacilli & Cocci \\
\hline Under 1,000 & 0 & 0 \\
$1,000-10,000$ & $0-5$ & $0-8$ \\
$10,000-100,000$ & $5-25$ & $8-30$ \\
Over 100,000 & 25 or more & 30 or more
\end{tabular}


FIG. 3. Calibration curve for Gram-negative bacilli. A significant number of colonies was found to be 25 .
FIG. 4. Calibration curve for Gram-positive cocci. A significant number of colonies was found to be 30 .

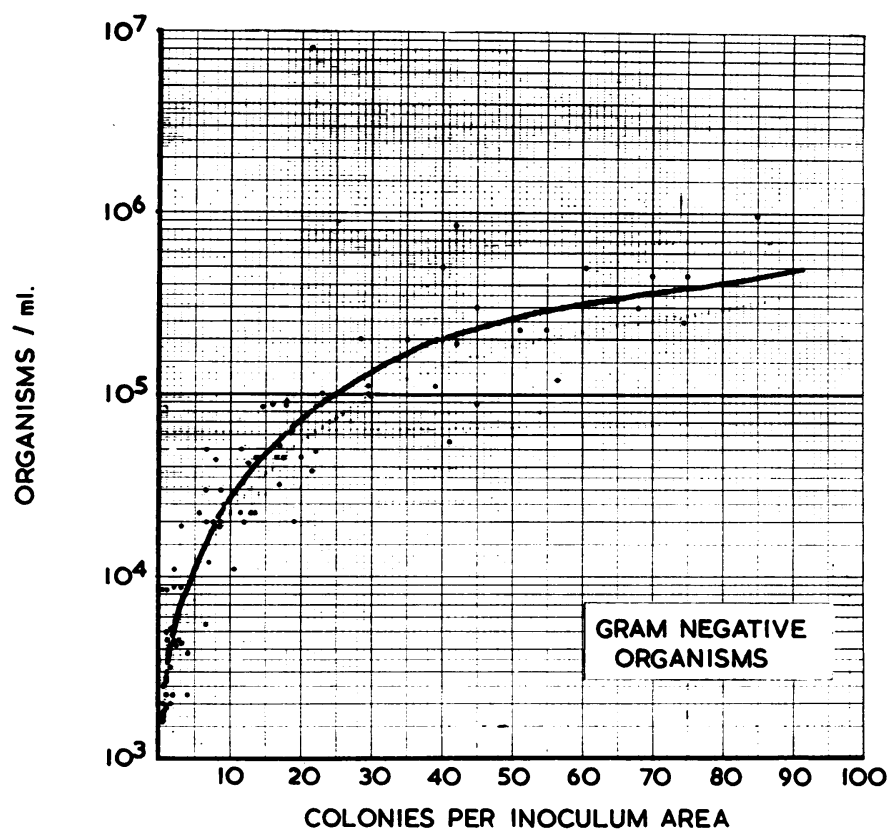

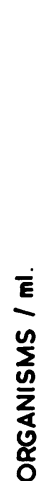

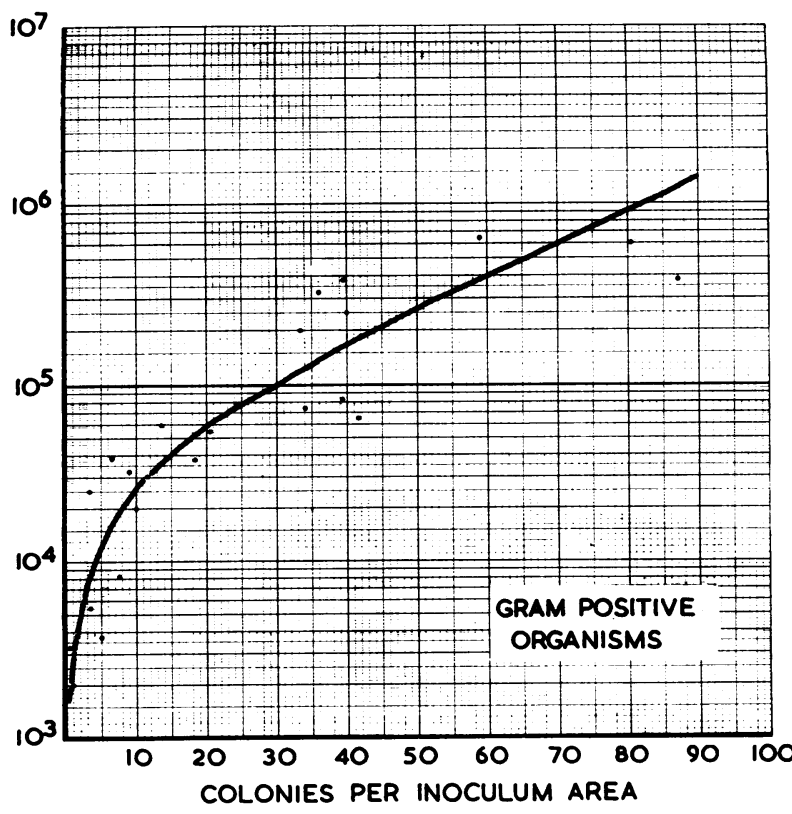

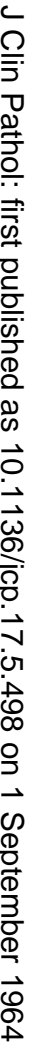


TABLE II

DISTRIBUTION OF TYPES AND NUMBERS OF ORGANISMS ISOLATED FROM URINES

\begin{tabular}{|c|c|c|c|c|c|c|c|}
\hline $\begin{array}{l}\text { Quantitative Count } \\
\text { (organisms/ml.) }\end{array}$ & Esch. coli & N.L.F.' & $\begin{array}{l}\text { Aerobacter } \\
\text { aerogenes }\end{array}$ & Staph. albus & Strep. faecalis & Mixed Growth & Total Urines \\
\hline $\begin{array}{l}\text { Over } 100,000 \\
10,000-100,000 \\
1,000-10,000\end{array}$ & $\begin{array}{l}49 \\
12 \\
20\end{array}$ & $\begin{array}{r}10 \\
7 \\
4\end{array}$ & $\begin{array}{l}1 \\
0 \\
0\end{array}$ & $\begin{array}{r}8 \\
64 \\
28\end{array}$ & $\begin{array}{r}1 \\
14 \\
58\end{array}$ & $\begin{array}{r}1 \\
59 \\
43\end{array}$ & $\begin{array}{r}70 \\
156 \\
153\end{array}$ \\
\hline
\end{tabular}

Under 1,000 organisms $/ \mathrm{ml} . \quad \ldots \ldots \ldots \ldots \ldots . \ldots 84$

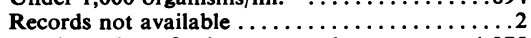

Total number of urines screened ...........

${ }^{1}$ N.L.F. = a non-lactose or late lactose-fermenting bacillus including species of Proteus, Paracolon, and a typical coliform.

SCREENING TESTS The total number of urines screened was 1,273 , and of these $1,047(82 \%)$ contained less than 10,000 organisms per ml. as judged by the surface viable count. One hundred and fifty-six (13\%) contained between 10,000 and 100,000 organisms per ml., and the remaining 70 contained over 100,000 organisms per ml., giving an incidence of significant bacteriuria of $5 \%$. The results of the screening programme on urines containing Gram-negative bacilli and Gram-positive cocci and the distribution of the organisms found is shown in Table II. Gram-negative bacilli accounted for $60(86 \%)$ of the significant results and Grampositive cocci were found in nine $(12 \%)$. One urine yielded a mixed growth of bacilli and cocci in numbers exceeding 100,000 . The most frequently occurring organism was Escherichia coli, present in pure culture in 49 of the urines, and other Gramnegative bacilli, such as Proteus mirabilis, were found in 11 urines. Of the nine urines containing significant numbers of Gram-positive cocci, eight contained Staph. albus and one Strep. faecalis.

A comparison was made between the results

\section{TABLE III}

COMPARISON OF POSITIVE RESULTS WITH T.T.C. AND BLOTTING-PAPER TESTS ${ }^{1}$

\begin{tabular}{|c|c|c|c|}
\hline Organism & $\begin{array}{l}\text { Total } \\
\text { Urines }\end{array}$ & T.T.C. Test & $\begin{array}{l}\text { Blotting-paper } \\
\text { Test }\end{array}$ \\
\hline \multicolumn{4}{|c|}{ Urines with $<100,000$ organisms per $\mathrm{ml}$. } \\
\hline \multicolumn{4}{|c|}{ Urines with $>100,000$ organisms per $\mathrm{ml}$. } \\
\hline Esch. coli & 49 & $38(80 \%)$ & $47(96 \%)$ \\
\hline N.L.F. ${ }^{2}$ & 10 & 10 & 10 \\
\hline Aerobacter aerogenes & 1 & 1 & 1 \\
\hline $\begin{array}{l}\text { Total for Gram-negative } \\
\text { bacilli }\end{array}$ & 60 & $49(81 \%)^{3}$ & $58(96 \%)$ \\
\hline Staph. albus & 8 & 2 & 6 \\
\hline Strep. faecalis & 1 & 1 & 1 \\
\hline Total for Gram-positive cocci & 9 & $3(33 \%)$ & $7(77 \%)$ \\
\hline Mixed growth & 1 & 0 & 1 \\
\hline Total for all organisms & 70 & $52(74 \%)$ & $66(94 \%)$ \\
\hline \multicolumn{4}{|c|}{$\begin{array}{l}\text { 'Assuming a colony count of } 25 \text { for bacilli and } 30 \text { for cocci to represent } \\
100,000 \text { organisms per } \mathrm{ml} \text {. } \\
2 \mathrm{~N} \text {.L.F. = a non-lactose or late lactose-fermenting bacillus including } \\
\text { species of Proteus, Paracolon, and atypical coliform. } \\
\text { In one urine there was no recorded result of a T.T.C. test having } \\
\text { been performed. }\end{array}$} \\
\hline
\end{tabular}

obtained by surface viable counting, the T.T.C. test, and the blotting-paper test (Table III). The surface viable count was accepted as the most accurate method and comparison of the results was made using this method as the standard. A positive result with either screening test when the number of bacteria present in the urine was less than 100,000 per $\mathrm{ml}$. was called a 'false positive' test. When the screening test was negative and more than 100,000 organisms per ml. were present the result was called a 'false negative'.

Of the 1,203 urines with bacterial counts less than 100,000 , nine $(0.7 \%)$ gave a false positive result with the T.T.C. test and nine $(0.7 \%)$ gave a false positive result with the blotting-paper test. These figures include one urine which gave a false positive test with both screening tests, whereas the surface viable count showed only 64,000 Esch. coli per ml. A repeat specimen of urine from this patient contained over 100,000 organisms per $\mathrm{ml}$.

Positive results in urines containing over 100,000 organisms per $\mathrm{ml}$. were given on 52 occasions out of 70 by the T.T.C. test $(74 \%)$ and on 66 occasions out of 70 by the blotting-paper test $(94 \%)$. The different species of organisms present were detected with varying degrees of accuracy. Both tests detected the urines containing significant numbers of nonlactose fermenting bacilli, but with Esch. coli the T.T.C. test detecting 38 out of 49 urines $(80 \%)$ was less accurate than the blotting-paper test which detected 47 of the 49 urines $(96 \%)$. Of the nine urines containing significant numbers of Grampositive cocci, the T.T.C. test detected only three $(33 \%)$ and the blotting-paper test detected seven $(77 \%)$. The urine which yielded a mixed growth of more than 100,000 organisms per $\mathrm{ml}$. gave a negative T.T.C. test and a positive blotting-paper test.

Four false negatives were obtained with the blotting-paper method, two in urines containing Esch. coli and two containing Staph. albus. In the two cases containing Esch. coli, one showed a blotting-paper test result of 90,000 organisms per $\mathrm{ml}$. as against a surface viable count of 40,000 organisms per $\mathrm{ml}$. The other showed a blotting-paper 
test of 50,000 organisms per ml., whereas the surface viable count was 150,000 organisms per ml.

The two false negatives with Staph. albus showed counts of 90,000 and 900 organisms per ml. by the blotting-paper test whereas the surface viable counts showed 100,000 and 500,000 organisms per ml. respectively.

It was found that in 72 urines no growth occurred on the inoculum area of the blotting-paper test whereas growth was present on the surface viable count plate. In none of these specimens, however, was the bacterial count more than 10,000 organisms per ml.

\section{DISCUSSION}

Many simplified methods of counting bacteria in the urine have been introduced. The majority are modifications of the surface viable count and depend on the use of standardized loops to avoid the use of pipettes and dilution of the urine (Hoeprich, 1960; O'Sullivan, Fitzgerald, Meynell, and Malins, 1960). In most methods at least one culture plate is needed for each test. Chemical tests such as the Griess nitrite test (Smith, Thayer, Malta, and Utz, 1961), the triphenyl tetrazolium chloride test (Simmons and Williams, 1962), and the $\alpha$ naphthyl tetrazolium test (Smith and Schmidt, 1962) were introduced as screening procedures to detect the presence or absence of infection but the degree of success with these tests has been variable and they are not quantitative procedures.

The blotting-paper test depends on the ability of blotting paper to adsorb a fairly constant volume of fluid. If the porosity of the paper is also constant the number of bacteria filtered out of the fluid and remaining on the surface of the paper will be proportional to the number of bacteria in the fluid. A measured area of the blotting paper is used to inoculate the surface of the culture medium. The most suitable paper is one which will adsorb fluid rapidly and yet will not allow too many organisms to be drawn into the centre of the paper. This theoretical basis explains the higher colony counts given by Gram-positive organisms as compared with the Gram-negative bacilli. The latter usually occur singly, whereas Gram-positive cocci, occurring in clumps or chains, have a greater mass and are more readily filtered out on to the surface of the paper.

The porosity and adsorptive power of blotting paper obtained from different manufacturers often varies, so that if a different paper is to be used it may be necessary to redraw the calibration curves.

In evaluating the blotting-paper test it was hoped that it might prove useful as a screening procedure for significant bacteriuria by providing an approximate quantitative count, being simple te perform and economical with materials and giving reliable results. In practice the only materials necessary were the paper strips and MacConke agar, the strips being used both to sample the urin and to inoculate the plate. The angulation of the blotting paper strip allowed easy application on tô the medium. Any paper strip which showed $a \vec{B}$ irregular inoculation area was discarded as it is necessary to bring the whole of the inoculation aresu of the strip into contact with the culture mediuns If only part of the paper is placed on the medium? falsely low counts will be recorded. It was als $\vec{Q}$ found necessary to wait a few seconds after samplingr to allow the urine to be completely adsorbed inteo the paper, otherwise a 'wet' impression is made $e_{0}^{\infty}$ giving falsely high counts. The amount of culture medium used is small; between eight and 10 urines can be tested in duplicate on the same plate becaus $\Phi$ the inoculum area is so small.

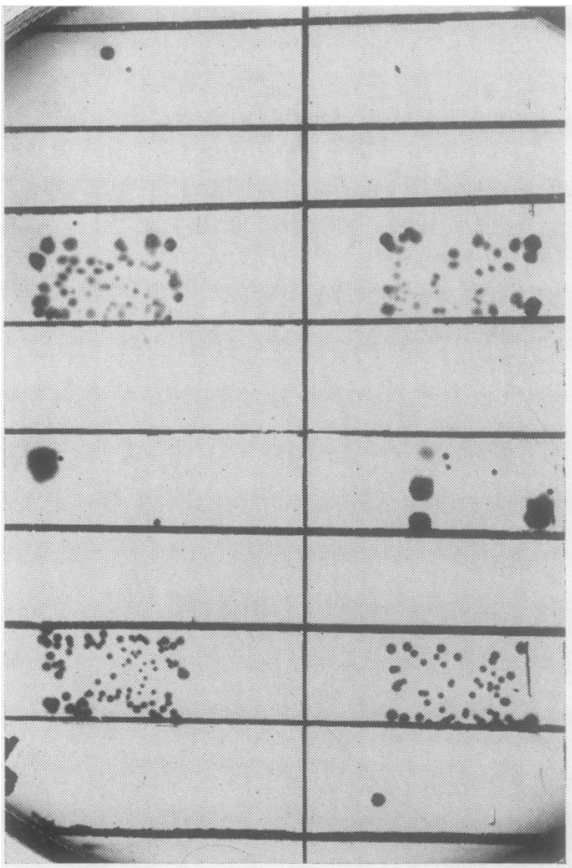

FIG. 5. Examples of eight screening tests. The quantitatives counts on these urines were as follows:-

16,000 mixed organisms per $\mathrm{ml}$.

2 under 1,000 organisms per $\mathrm{ml}$.

3 over 100,000 Esch. coli per $\mathrm{ml}$.

4 under 1,000 organisms per $\mathrm{ml}$.

516,000 mixed organisms per $\mathrm{ml}$.

6 Under 1,000 organisms per $\mathrm{ml}$.

7 over 100,000 Esch. coli per $\mathrm{ml}$.

8 under 1,000 organisms per $\mathrm{ml}$. 
Dilution is not necessary as the number of colonies represented by the accepted level of bacteriuria which constitutes an infection, namely 100,000 organisms per ml., is approximately 25 and therefore can easily be counted. The time taken to make impressions from 20 urines is approximately 15 minutes.

The results of the tests were in practice easy to read and a sample plate is shown in Figure 5 . Urines containing over 1 million organisms per $\mathrm{ml}$. usually give a confluent growth on the inoculum area and urines containing 100,000 to 1 million organisms per ml. give an almost confluent growth and can be picked out at a glance. When 10,000 to 100,000 organisms per ml. are present in the urine, the number of colonies varies from five to 30 . This number can be readily counted and the approximate bacterial count can be obtained from the calibration curves (Figs. 3 and 4). These urines are clinically important because when repeat specimens were collected over $40 \%$ contained over 100,000 organisms per ml. Counts of less than 10,000 organisms per $\mathrm{ml}$. give very few colonies on the inoculum area, and when less than 1,000 organisms per ml. are present there is frequently no growth. Identification of the organism can be tested for in the usual way by picking colonies off the plate with a straight wire.

The results of the T.T.C. tests in this series were disappointing as only $81 \%$ of the Gram-negative bacillurias were detected. In the original series on hospital patients $95 \%$ of infections were detected (Simmons and Williams, 1962).

The difference is probably due to the different numbers of organisms in the urines from the two groups of patients. This series included an appreci- able number of urines containing between 100,000 and 500,000 organisms per $\mathrm{ml}$. at which level the T.T.C. test is less likely to be positive. We have found that the blotting-paper test is more reliable, although slower to give a result than the T.T.C. test when used as a screening procedure for bacteriuria, and that it compares favourably with the surface viable count.

One factor which played a large part in the satisfactory result was the nature of the specimen examined. The urines were taken after careful vulval toilet and were refrigerated at $4^{\circ} \mathrm{C}$. immediately. Bacteriological examination of the urine, including screening tests, can only give satisfactory results if the specimens are adequately taken and cared for.

We wish to thank Dr. W. Brumfitt, Dr. A. Percival, and Dr. N. A. Simmons for advice and encouragement. The collection of the specimens of urine was supervised by the sister in charge of the ante-natal clinic at Edgware General Hospital, Miss R. Faint, S.R.N., S.C.M., M.T.D.

\section{REFERENCES}

Hoeprich, P. D. (1960). J. Lab. clin. Med., 56, 899.

Kaitz, A. L., and Hodder, E. W. (1961). New Engl. J. Med., 265, 667.

Kass, E. H. (1956). Trans. Ass. Amer. Phycns., 69, 56.

Miles A. A. and Misra S. S. $1938 J$ Hyg. (Lond.), 38, 732.

Monzon, O. T., Armstrong, D., Pion, R. J., Deigh, R., and Hewitt, W. L. (1963). Amer. J. Obstet. Gynec., 85, 511.

O'Sullivan, D. J., Fitzgerald, M. G., Meynell, M. J., and Malins, J. M. (1960). J. clin. Path., 13, 527.

Ryan, W. L., Hoody, S. and Luby, R. (1962). J. Urol. (Baltimore), 88, 838.

Simmons, N. A., and Williams J. D. (1962). Lancet, 1, 1377.

Smith, L. G., Thayer, W. R., Malta, E. M., and Utz, J. P. (1961). Ann. intern. Med., 54, 66.

—, and Schmidt, J. (1962). J. Amer. med. Ass., 181, 431. 